\title{
PERBANDINGAN EFEKTIVITAS DAYA HAMBAT INFUSUM DAUN SIRIH (PIPERBETIE L) DAN DAUN MENGKUDU (MORINDA CITROFILIA L) TERHADAP PERTUMBUHAN JAMUR CANDIDA ALBICANS
}

\author{
Shara Lutfiyona Ikhsan ${ }^{1}$, Detty Iryani ${ }^{1}$, Nelvi Yohana ${ }^{1}$ \\ ${ }^{1}$ Fakultas Kedokteran Gigi Universitas Andalas
}

\begin{abstract}
Many people tend to consider using plants for medicine. Beatle's leaves are contained of some active substance such as kavikol,kavibetol and eugenol while mengkudu's leave have active substance such as Scalopoetin, antrhakuinon and saponin that known as antifungi. One of fungi as the main agent of Candidiasis diseases in mouth is Candida albicans. The purpose of study is to compairing the difference inhibitions activity of infusion beatle's Leaves (Piper beatle L) and infusion mengkudu's leaves (Morinda citrofilia L) against Candida albicans growth. The Study use dilution method to determine of Minimun Inhibitory Concentration (MIC). This research using 32 sample of infusion beatle's leaves and infusion mengkudu's leaves and mixing with Candida albicans and then incubation with Sabouroud Dextrose Broth media. The result is concentration $80 \%$ of infusion beatle's leaves had an inhibitions power against Candida albicans growth. Concentration 100\% infusion mengkudu's leaves had an inhibitions power against Candida albicans growth.The Conclusion of the study is concentration needed of infusion beatle's leaves low than infusion mengkudu's leaves for inhibition against Candida albicans growth.
\end{abstract}

Keywords: beatle's leaves, mengkudu's leaves, Minimun Inhibitory Concentration, Candida albicans

Affiliasi penulis: ${ }^{1}$ Fakultas Kedokteran Gigi Universitas Andalas Korespondensi: Nelvi Yohana, email: nelviyohana@yahoo.com

\section{PENDAHULUAN}

Salah satu permasalahan kesehatan di Indonesia adalah tingginya penyakit gigi dan mulut. Hal ini disebabkan oleh banyaknya masyarakat di Indonesia yang menganggap bahwa menjaga kesehatan gigi dan mulut adalah hal yang kurang penting. Berdasarkan data Riskesdas pada tahun 2013, didapatkan bahwa prevalensi penyakit gigi dan mulut nasional adalah sekitar 25,9\%. Dari jumlah tersebut, hanya $31,1 \%$ saja masyarakat dengan penyakit gigi dan mulut yang menerima pengobatan atau perawatan dari tenaga medis gigi (perawat gigi, dokter gigi dan dokter spesialis gigi), sementara itu 68,9 $\%$ sisanya tidak mendapat pengobatan ataupun perawatan sama sekali ${ }^{1}$.

Selain rendahnya kesadaran masyarakat untuk berobat atau merawat penyakit gigi dan mulut kepada tenaga medis, ketersedian tenaga medis untuk mengatasi penyakit gigi dan mulut juga kurang merata. Hal ini membuat masyarakat harus mengerti cara mengobati penyakit gigi dan mulut yang dialami dengan memanfaatkan bahanbahan yang mudah didapat, seperti tanaman atau tumbuhan. Pada dasarnya Indonesia memiliki kekayaan hayati yang sangat beragam dan dapat 
dimanfaatkan untuk pengobatan secara tradisional, termasuk pengobatan masalah gigi dan mulut ${ }^{2}$.

Salah satu penyakit gigi dan mulut yang dapat diobati menggunakan daun sirih dan daun mengkudu adalah Candidiasis. Penyakit ini disebabkan oleh jamur spesies Candida albicans yang merupakan flora normal pada rongga mulut. Namun, jamur ini dikenal memiliki sifat oportunistik, yang dapat menyebabkan infeksi dan kerusakan jaringan pada keadaan tertentu. Candida albicans bukan mikroorganisme tunggal yang menyebabkan denture stomatitis, namun mikroorganisme dominan pada denture stomatitis ${ }^{3}$.

Kandungan daun sirih terdiri dari eugenol, metil eugenol, karvakrol, kavikol, alil katekol, kalribetol, sineol, estragol, karoten, tiamin, riboflavin, asam nikotinat, vitamin C, Tanin, gula, pati dan asam amino. Selain itu, dalam daun sirih juga terdapat minyak atsiri yang terdiri atas kurang lebih 30\% fenol derivate antara lain kovikol dan betlephenol yang memiliki daya antiseptik dan anti mikotik sangat kuat sehingga dapat mengatasi atau mengobati penyakit gigi dan mulut seperti Candidiasis ${ }^{4}$.

Kandungan yang terdapat pada daun mengkudu adalah antrhakinon, scoloptin, saponin, catechin, serat kasar protein, zat kapur, karoten, asam askorbat, asam amino utuh, dan vitamin $A$. Diantara berbagai kandungan tersebut pada daun mengkudu, senyawa yang sangat penting dalam mengobati penyakit gigi dan mulut adalah antrhakinon, scoloptin, saponin, karena berfungsi sebagai antimikroba dan antijamur, sedangkan pada daun sirih senyawa kavikol, kavibetol dan eugenol yang memiliki daya antiseptik dan antimikotik yang kuat ${ }^{5,6}$.

Jika dilihat berdasarkan diameter zona hambat terhadap Candida albicans, infusum daun sirih dengan konsentrasi $250 \mathrm{mg} / \mathrm{ml}$ menghasilkan diameter zona hambat sebesar 10,43 $\mathrm{mm}$, pada konsentrasi $500 \mathrm{mg} / \mathrm{ml}$ mengahasilkan diameter zona hambat sebesar 12,33 mm dan pada konsentrasi $1000 \mathrm{mg} / \mathrm{ml}$ menghasilkan diameter zona hambat sebesar 16,80 $\mathrm{mm}^{7}$. Sementara itu, penelitian lain menggunakan ekstrak buah mengkudu untuk mengetahui diameter zona hambat terhadap jamur yang sama. Pada konsentrasi $4 \%$, didapatkan diameter zona hambat sebesar 2,01 mm, konsentrasi $6 \%$ menghasilkan diameter zona hambat 2,16 $\mathrm{mm}$ serta konsentrasi $8 \%$ menghasilkan diameter zona hambat sebesar $2,2 \mathrm{~mm}^{8}$.

Berdasarkan pemaparan uraian di atas, dapat dilihat bagaimana pengaruh daun sirih dan daun mengkudu terhadap jamur Candida albicans, 
namun masih jarang metode infusum yang dilakukan. Metode ini diharapkan dapat dicontoh oleh masyarakat karena mudah dilakukan dibanding metode ekstrak, serta informasi yang berhubungan tentang pemanfaatan daun sirih dan daun mengkudu yang berkembang di masyarakat masih sebatas bukti empiris dan belum banyak informasi secara ilmiah tentang khasiat kandungan daun sirih dan daun mengkudu terhadap pertumbuhan jamur Candida albicans.

\section{METODE}

Jenis penelitian yang dilakukan adalah eksperimental laboratorium. Penelitian dilakukan dilaboratorium Mikrobiologi Fakultas Teknologi Hasil Pertanian Universitas Andalas pada bulan Desember 2014. Populasi dalam penelitian ini adalah jamur Candida albicans, sedangkan sampel dalam penelitian ini adalah Sampel dalam penelitian ini adalah biakan murni jamur Candida albicans yang berasal dari Laboratorium Mikrobiologi Fakultas Kedokteran Universitas Andalas. Besar sampel dalam penelitian ini dihitung menggunakan rumus Fredere dan didapatkan hasil bahwa jumlah perlakuan (n) yang dipakai adalah 2, artinya pada kelompok I-XVI (16 variabel) dilakukan sebanyak 2 kali percobaan.
Metode yang digunakan dalam penelitian ini adalah eksperimental laboratorium dengan tujuan membandingkan efektifitas daya hambat infusum daun sirih dan daun mengkudu terhadap pertumbuhan jamur Candida albicans. Penelitian ini dilakukan di Laboratorium Mikrobiologi Fakultas Teknologi Hasil Pertanian Universitas Andalas pada tanggal 17 - 19 Desember 2014.

Penelitian untuk mengetahui Kadar Hambat Minimal (KHM) pertumbuhan Candida albicans dengan metode dilusi cair menggunakan infusum daun sirih dan daun mengkudu. Konsentrasi yang digunakan masing masing 30\%, 40\%, 50\%, 60\%, 70\%, $80 \%$, 90\%, dan 100\%. Masing masing konsentrasi infusum tersebut dicampur dengan biakan jamur Candida albicans sebanyak 1 - 2 ose kemudian dihomogenkan menggunakan vortex dan didiamkan selama 10 menit, selanjutnya campuran infusum dan jamur Candida albicans tersebut dimasukkan ke dalam media Sabouraud Dextrose Broth dan diinkubasi selama 48 jam pada suhu $37^{\circ} \mathrm{C}$.

Pengamatan dilakukan setelah 48 jam untuk melihat Kadar Hambat Minimal (KHM), yang ditandai dengan ada atau tidaknya kekeruhan pada media. Percobaan dengan 16 kelompok perlakukan dilakukan dalam satu waktu 
dengan perlakukan yang sama. Hasil penelitian ini diperoleh melalui pengamatan serta observasi terhadap perubahan kekeruhan pada media dan dianalisis secara deskriptif.

\section{HASIL DAN PEMBAHASAN}

\section{Berdasarkan pengamatan} terhadap kekeruhan media, pada infusum daun sirih dengan konsentrasi $80 \%, 90 \%$ dan $100 \%$ tidak menunjukkan kekeruhan, yang berarti tidak terdapat pertumbuhan jamur Candida albicans. Sementara itu, media yang sama dengan konsentrasi $30 \%, 40 \%, 50 \%, 60 \%$ dan 70\% menunjukkan kekeruhan, yang berarti terdapat pertumbuhan jamur Candida albicans.

Tabel 1. Konsentrasi Infusum Daun Sirih (Piperbetie L) Terhadap Pertumbuhan Jamur Candida albicans

\begin{tabular}{ccc}
\hline No & $\begin{array}{c}\text { Konsentrasi } \\
\text { Infusum } \\
\text { Daun Sirih } \\
\text { (Piperbetie L) }\end{array}$ & $\begin{array}{c}\text { Pertumbuhan } \\
\text { Jamur } \\
\text { Candida } \\
\text { albicans }\end{array}$ \\
\hline 1 & $30 \%$ & + \\
2 & $40 \%$ & + \\
3 & $50 \%$ & + \\
4 & $60 \%$ & + \\
5 & $70 \%$ & + \\
6 & $80 \%$ & - \\
7 & $90 \%$ & - \\
8 & $100 \%$ & - \\
\hline
\end{tabular}

Tabel 2. Hasil Penelitian Efektivitas Daya Hambat Infusum Daun Mengkudu (Morinda Citrofolia L) Terhadap Pertumbuhan Jamur Candida albicans

\begin{tabular}{ccc}
\hline No & $\begin{array}{c}\text { Konsentrasi } \\
\text { Infusum Daun } \\
\text { Mengkudu } \\
\text { (Morinda } \\
\text { Citrofolia L) }\end{array}$ & $\begin{array}{c}\text { Pertumbuhan } \\
\text { Jamur } \\
\text { Candida } \\
\text { albicans }\end{array}$ \\
\hline 1 & $30 \%$ & + \\
2 & $40 \%$ & + \\
3 & $50 \%$ & + \\
\hline
\end{tabular}

\begin{tabular}{lcc}
\hline 4 & $60 \%$ & + \\
5 & $70 \%$ & + \\
6 & $80 \%$ & + \\
7 & $90 \%$ & + \\
8 & $100 \%$ & - \\
\hline
\end{tabular}

Berdasarkan tabel di atas, dapat disimpulkan bahwa pada media dengan infusum daun mengkudu pada konsentrasi $100 \%$ tidak menunjukkan kekeruhan, yang berarti tidak terdapat pertumbuhan jamur Candida albicans. Sementara itu, media dengan konsentrasi 30\%, 40\%, 50\%, 60\%, 70\%, $80 \%$ dan $90 \%$ menunjukkan kekeruhan, yang berarti terdapat pertumbuhan jamur Candida albicans.

Berdasarkan penelitian yang dilakukan Koesmiati pada tahun 1996, dimana dalam infusum daun sirih terkandung zat aktif kavikol, kavibetol dan eugenol yang merupakan senyawa turunan fenol yang memiliki daya antifungi. Komponen penyusun minyak atsiri daun sirih terdiri dari $82,8 \%$ senyawa fenol dan $18,2 \%$ senyawa bukan fenol. Senyawa fenol yang merupakan komponen utama minyak atsiri berperan sebagai anti mikroba dari daun $\operatorname{sirih}^{9}$. Lambatnya pertumbuhan koloni jamur pada perlakuan pemberiaan infusum daun sirih diduga karena telah terjadi reaksi antara senyawa anti jamur dari infusum daun sirih terhadap jamur Candida albicans. Semakin besar konsentrasi infusum daun sirih yang diberikan berarti kandungan fenol semakin banyak dan reaksi yang 
ditimbulkan akan semakin kuat ${ }^{10}$. Lay dan Hastowo (2003) menjelaskan mekanisme kerja fenol dengan cara merusak membran plasma jamur. Senyawa ini juga menyebabkan lisis pada sel dan dapat merusak sistem kerja sel. Kehadiran fenol yang merupakan senyawa antimikrobial juga mengakibatkan struktur tiga dimensi protein terganggu dan terbuka menjadi struktur acak tanpa adanya kerusakan pada struktur kerangka kovalen. Hal ini menyebabkan protein terdenaturasi. Deret asam amino protein tersebut tetap utuh setelah denaturasi, namun aktifitas biologisnya menjadi rusak sehingga protein tidak melakukan fungsinya.

Penelitian yang dilakukan oleh Galuh tahun 2013, yaitu senyawa antrakuinon yang terdapat dalam buah mengkudu merupakan golongan dari terpenoid dan turunan dari senyawa fenol. Senyawa fenol yang terdapat pada buah mengkudu berkisar antara 5,94$36,52 \mathrm{~g} / 100 \mathrm{~g}$ material kering. Adisoemarto pada tahun 1998 menjelaskan bahwa golongan fenol mampu merusak membran sel, menginaktifkan enzim dan mendenaturasi protein pada jamur sehingga dinding sel jamur akan mengalami kerusakan karena terjadinya penurunan permeabilitas yang memungkinkan terganggunya transport ion-ion organik penting yang akan masuk ke sel jamur. Hal ini akan mengakibatkan pertumbuhan sel terhambat dan sel akan mengalami kematian. Oleh karena itu fenol berperan sebagai senyawa antijamur.

Senyawa antrakuinon pada buah mengkudu berperan dalam efek penghambatan pertumbuhan jamur. Mekanisme kerja dari senyawa ini adalah mengganggu komponen penyusun pada dinding sel, sehingga lapisan dari dinding sel tidak dapat terbentuk sempurna dan mekanisme tersebut dapat menyebabkan kematian $\operatorname{sel}^{11}$.

Senyawa saponin bekerja sebagai antijamur pada buah mengkudu dengan mengganggu stabilitas membran sel jamur sehingga menyebabkan sel jamur lisis. Mekanisme kerja saponin termasuk dalam kelompok antimikroba yang mengganggu permeabilitas membran sel jamur, yang mengakibatkan kerusakan membran sel dan menyebabkan keluarnya berbagai komponen penting dari dalam sel ${ }^{12}$.

Penelitian lain yang dilakukan Cornelia pada tahun 2013 juga sesuai dengan hasil penelitian ini. Kandungan scopoletin, antrhakinon dan saponin pada buah mengkudu dapat menghambat pertumbuhan jamur Candida albicans. Pada penelitian tersebut konsentrasi ektrak mengkudu 4\%, didapatkan diameter zona hambat sebesar 2,01 mm, 
konsentrasi $6 \%$ menghasilkan diameter zona hambat 2,16 mm serta konsentrasi $8 \%$ menghasilkan diameter zona hambat sebesar 2,2 $\mathrm{mm}$. Dari hasil penelitian tersebut dapat disimpulkan bahwa semakin tinggi kosentrasi ekstrak buah mengkudu semakin besar daya hambat terhadap pertumbuhan jamur Candida albicans.

Berdasarkan uraian diatas dapat disimpulkan, konsentrasi yang diperlukan infusum daun sirih dalam menghambat pertumbuhan jamur Candida albicans lebih rendah dibandingkan infusum daun mengkudu yang kemungkinan disebabkan oleh kandungan senyawa fenol dan turunannya yang tinggi pada daun sirih $(82,8 \%)$ yang berperan dalam menghambat pertumbuhan jamur Candida albicans.

\section{SIMPULAN}

Berdasarkan penelitian yang dilakukan, diperoleh hasil bahwa Kadar Hambat Minimal infusum daun sirih terhadap pertumbuhan jamur Candida albicans adalah pada konsentrasi $80 \%$, smentara itu kadar Hambat Minimal infusum daun mengkudu terhadap pertumbuhan jamur Candida albicans adalah pada konsentrasi 100\%. Dengan kata lain, konsentrasi infusum daun sirih yang diperlukan dalam menghambat pertumbuhan jamur Candida albicans lebih rendah dibandingkan infusum daun mengkudu.

\section{KEPUSTAKAAN}

1. Kementrian Kesehatan Republik Indonesia. Laporan Nasional Riset Kesehatan Dasar (RISKESDAS). Badan Penelitian dan Pengembangan Kesehatan Departemen Kesehatan Republik Indonesia. 2013.

2. Suwondo. Skrining Tumbuhan Obat Yang Mempunyai Aktivitas Anti Bakteri Penyebab Karies Gigi dan Pembentukan Plak. Jurnal Bahan Alam Indonesia 6(2): 2007; 65-72.

3. Andi, Nur Mayati. Pengaruh Larutan Ekstrak Daun Sirih Terhadap Perubahan Warna Basis Resin Akrilik Heat Cured. Fakultas Kedokteran Gigi Universitas Hasanudin. 2013.

4. Erna, Herawati. Uji Efek Anti Jamur Fraksi N-Heksana Dan Etil Asetat Daun Sirih ( Piper Betle L. ) Terhadap Candida albicans ( Isolat Gigi Tiruan Lengkap Akrilik Rahang Atas ). Pustaka Ilmiah Universitas Padjajaran. Bandung: 2013.

5. Dian, Fatihah Imami. Aktivitas Antibakteri Ekstrak Campuran Daun Kayu Manis dan Mengkudu Dengan Pelarut Metanol Terhadap 
Bakteri Patogen Saluran

Pencernaan Unggas. Skripsi. 2013

6. Kristin, Ningrum. Dahsyatnya

Khasiat Herbal Untuk Hidup Sehat.

Jakarta : Dunia Sehat. 2013.

7. Atiek, Soemiati. Uji Pendahuluan

Efek Kombinasi Antijamur Infus

Daun Sirih (Piper Betle L.), Kulit

Buah Delima (Punica Granatum L.),

Dan Rimpang Kunyit (Curcuma

Domestica Val.) Terhadap Jamur

Candida albicans. 2002. MAKARA,

SERI SAINS Vol.6 No. 3

8. Cornelia, Pary. Pengaruh Ekstrak

Buang Mengkudu (Morinda

Citrofolia L) Terhadap

Pertumbuhan Jamur Candida

albicans. Prosiding FMIPA

Universitas Pattimura 978(5): 2013;

194-199

9. Soerya Dewi. Aktivitas Antibakteri Minyak Atsiri Daun Sirih Merah (Piper crocatum ruiz \& pav.), Jurusan Kimia, Fakultas Matematika dan Ilmu Pengetahuan Alam, Universtas Sebelas Maret, Kentingan Surakarta. 2013: 7.

10. Achmad Achmad, Suryana I. Pengujian Aktivitas Ekstrak Daun Sirih (Piper Betle Linn.) Terhadap Rhizoctonia Sp. Secara In Vitro. 2009 Vol 1 (1).

11. Dwidjoseputo, D. Dasar Dasar Mikrobiologi. Djambatan. Jakarta: 1994; 97-99
12. Ganiswarna, S. Farmakologi dan Terapi, Ed. Ke-5. Penerbit UI, Jakarta. 2007. 